University of Nebraska - Lincoln

DigitalCommons@University of Nebraska - Lincoln

Mammalogy Papers: University of Nebraska

State Museum

Museum, University of Nebraska State

2010

\title{
Observations of Reproduction in Mountain Lions from Nebraska
}

Sam Wilson

Nebraska Game and Parks Commission

Justin D. Hoffman

McNeese State University, jhoffman@mcneese.edu

Hugh H. Genoways

University of Nebraska-Lincoln, h.h.genoways@gmail.com

Follow this and additional works at: https://digitalcommons.unl.edu/museummammalogy

Part of the Terrestrial and Aquatic Ecology Commons, and the Zoology Commons

Wilson, Sam; Hoffman, Justin D.; and Genoways, Hugh H., "Observations of Reproduction in Mountain Lions from Nebraska" (2010). Mammalogy Papers: University of Nebraska State Museum. 126.

https://digitalcommons.unl.edu/museummammalogy/126

This Article is brought to you for free and open access by the Museum, University of Nebraska State at DigitalCommons@University of Nebraska - Lincoln. It has been accepted for inclusion in Mammalogy Papers: University of Nebraska State Museum by an authorized administrator of DigitalCommons@University of Nebraska Lincoln. 


\title{
OBSERVATIONS OF REPRODUCTION IN MOUNTAIN LIONS FROM NEBRASKA
}

\author{
Sam Wilson ${ }^{1}$, Justin D. Hoffman ${ }^{2,4}$, and Hugh H. Genoways ${ }^{3}$
}

\begin{abstract}
Occurrences of mountain lions (Puma concolor) in Nebraska have been steadily increasing; however, reproductive activity in mountain lions has not been documented in the state. We present the first evidence of mountain lion reproduction in Nebraska since mountain lions recolonized the state in the early 1990s. On 28 February 2007, a spotted kitten was hit by a vehicle in northwestern Nebraska; and based on body length and weight, we estimate its age at 3.9 months. On 20 December 2008, a female mountain lion and spotted kitten were photographed in the northwestern part of the state. On 9 May 2009, a female mountain lion with a juvenile was also photographed. All records were from the Pine Ridge region of Dawes County, Nebraska. Our records suggest that mountain lions are establishing a permanent population in at least one region of Nebraska.
\end{abstract}

Key words: mountain lion, Puma concolor, reproduction, Nebraska, Pine Ridge.

Mountain lions (Puma concolor) once occurred throughout Nebraska until they were extirpated in the early 1900s (Jones et al. 1964). Recently, records of mountain lions have been reported in Nebraska as early as 1991 (Genoways and Freeman 1996), but reproductive activity in mountain lions has yet to be documented since their recolonization of the state. On 28 February 2007 at about 19:15 (Mountain Standard Time), a spotted female kitten was killed by an automobile $15.1 \mathrm{~km}$ east of Chadron on U.S. Highway 20, Dawes County, Nebraska. The cranium and partial skeleton of the individual were deposited in natural history collections in the Division of Zoology, University of Nebraska State Museum (UNSM 29173). When salvaged, the kitten measured $1245 \mathrm{~mm}$ in length and weighed $11.9 \mathrm{~kg}$. Cranial measurements $(\mathrm{mm})$ were as follows: greatest length of skull, 134.0; zygomatic breadth, 94.7; interorbital breadth, 26.6; postorbital breadth, 43.3; length of nasals, 31.3; breadth across upper canines, 40.7; length of palate (anterior edge of palatine to posterior margin of incisive foramina), 37.7; length of maxillary toothrow (dC-dP4), 40.7; length of auditory bullae, 24.1; length of mandibular toothrow (dc-dp4), 37.0; and length of mandible, 91.7.

We used several publications to help determine age of this kitten. Robinette et al. (1961) created a growth curve for weight based on a few known-age mountain lions from Utah and Nevada. This growth curve yielded the oldest age estimate of 5 months. Anderson and Lindzey (2000) determined that deciduous canines of mountain lion kittens are fully erupted (10 $\mathrm{mm}$ in length) at about 4 months. In our specimen, all deciduous teeth are fully erupted, permanent incisors are beginning to appear, and deciduous canines extend $10.3 \mathrm{~mm}$ beyond the gum line (Table 1). Thus, based on these criteria, the kitten is about 4 months old. Laundré and Hernández (2002) developed growth curves for estimating the age of young mountain lions from the northern Great Basin based on total length and weight. Using their formulas, age of the kitten is 4.75 months based on weight and 4.9 months based on length. However, use of mountain lions from the Great Basin for age determination tended to overestimate the ages for 13 known-age mountain lions from Wyoming by about 1.47 months (C.R. Anderson, personal communication, 26 May 2009). This discrepancy may also apply to estimating the age of mountain lions in Nebraska (see Anderson et al. 2004); thus the approximate ages of our specimen would be 3.28 and 3.43 months, respectively. The average of these 4 estimates results in a final age estimate of 3.9 months for the Nebraska kitten.

1Nebraska Game and Parks Commission, 2200 N 33rd Street, Lincoln, NE 68503.

${ }^{2}$ Department of Biological and Health Sciences, McNeese State University, Lake Charles, LA 70609.

${ }^{3}$ University of Nebraska State Museum, W436 Nebraska Hall, Lincoln, NE 68588-0514.

${ }^{4}$ Corresponding author. E-mail: jhoffman@mcneese.edu 
TABLE 1. Condition of teeth for a female mountain lion (Puma concolor) from Nebraska (UNSM 29173) with an estimated age of 3.9 months; $\mathrm{d}=$ deciduous teeth.

\begin{tabular}{ll}
\hline Teeth & \multicolumn{1}{c}{ Condition } \\
\hline Upper teeth & Right and left incisors are both adult teeth \\
I1 & Adult replacement incisors visible deep in alveoli \\
dI2-3 & Adult replacement canines visible deep in alveoli \\
dC & Adult replacement premolars visible deep in alveoli \\
dP2 & No replacement premolars visible and no alveolar openings \\
dP3 & No replacement premolars visible and no alveolar openings \\
dP4 & Adult molar clearly visible in alveolus but not erupted above the level of the jaw \\
M1 & \\
Lower teeth & Right and left incisors are both adult teeth \\
i1 & Right incisor is adult tooth \\
i2 & Left deciduous and permanent incisors are both present \\
di2/i2 & Adult replacement incisors visible deep in alveoli \\
di3 & Adult replacement canine visible deep in alveoli \\
dc & No replacement premolars visible and no alveolar openings \\
dp3 & No replacement premolar visible and no alveolar openings \\
dp4 & Adult molar clearly visible in alveolus, with posterior portion raised near level of gum line \\
m1 & \\
\hline
\end{tabular}

Because of the age of the kitten (see above) and known restricted movements of female mountain lions with kittens (Grigione et al. 2002), we suspect that this kitten represents the first documentation of reproduction in mountain lions in Nebraska since they recolonized the state in the early 1990s (Genoways and Freeman 1996). During the past 2 decades, the increasing presence of mountain lions in Nebraska has been attributed to dispersal of animals primarily from eastern Wyoming and the Black Hills of South Dakota (Benedict et al. 2000, Hoffman and Genoways 2006). We infer, based on our observations, that reproduction by lions in the state is also contributing to increases in the number of individuals. The driver of the automobile that hit this kitten stated that it was accompanied by its mother and 2 other kittens. The day before (27 February 2007) and near this location, a female lion and 2 kittens were photographed by Michael Forsberg, a professional wildlife photographer, confirming the presence of a female mountain lion with multiple kittens in the area (Forsberg 2009). It is possible that these 2 observations were of the same family unit; however, this could not be verified. Additional evidence of reproduction in the state was subsequently documented by Steve Masek (Nebraska Game and Parks Commission) who observed and photographed with a trail camera a female and spotted kitten $16.9 \mathrm{~km}$ southeast of Chadron, Dawes County, on 20 December 2008. On 9 May 2009, what we believe to be a female mountain lion and a nearly grown juvenile were photographed together in the same area (Forsberg 2009). Again, it is possible that these 2 observations were of the same family unit, but we could not confirm this based on photographs.

Mountain lions can be born in any month of the year (Seton 1929:85; Young and Goldman 1946:114). Based on our age estimation, the kitten hit by the vehicle was likely born in late October or early November 2006. Mountain lions have a gestation period of 93 (89-98) days (Eaton and Verlander 1977, Hemmer 1977); thus copulation would have occurred in late July or early August 2006. Data from Nebraska demonstrate a potential range in litter size from 1 to 3 kittens, which is similar to other published sources. Robinette et al. (1961) documented 131 litters with a mean postnatal litter size of $3.0(1-5)$ kittens, and litters of 2 $(31 \%)$ and $3(47 \%)$ far outnumbering others. Eaton and Verlander (1977) observed that in 35 litters of captive mountain lions in Washington, mean litter size was 2.6 (1-5), with litters of $2(40 \%)$ and $3(26 \%)$ being the most common.

All reproductively active mountain lions were sighted in the Pine Ridge region of Nebraska. This area of rugged hills forms an arc between the Niobrara and White rivers in Nebraska (Sioux, Dawes, and Sheridan counties) to southern South Dakota (Bennett and Shannon counties). This arc of pine-covered hills extends about $160 \mathrm{~km}$ west to east and ranges up to 32 $\mathrm{km}$ in width. The Pine Ridge is ecologically similar to the Black Hills of South Dakota, which lie $80 \mathrm{~km}$ to the north, but are separated by an area of short-grass prairie and 
badlands. The site where the kitten was hit on U.S. Highway 20 parallels Little Bordeaux Creek. The area contains deciduous trees dominated by cottonwood (Populus spp.) and hackberry (Celtis spp.) in the valley and ponderosa pine (Pinus ponderosa) in the surrounding hills. We do not find it surprising that the first records of reproduction in Nebraska are from the Pine Ridge because of its habitat similarities and proximity to locations in South Dakota and Wyoming that possess stable populations of mountain lions.

Our observations also provided data on food habits of mountain lions in Nebraska. Photographs of a female mountain lion and kitten taken on 20 December 2008 show that they were feeding on a male mule deer (Odocoileus hemionus). The deer population in Nebraska has been increasing for many years (Nebraska Game and Parks Commission 2009) and undoubtedly is providing a resource for the expansion of mountain lions in the state. Additionally, a porcupine (Erethizon dorsatum) quill was found embedded in the tail of the kitten killed by the vehicle. Young and Goldman (1946) consider porcupines "one of the favorite foods of the puma." Porcupines are common in the Pine Ridge and currently occur across at least the western two-thirds of the state (Genoways et al. 2008).

We are particularly grateful to Charles $\mathrm{R}$. Anderson Jr. (Mammal Research, Colorado Division of Wildlife, Grand Junction, CO) for sharing his insights into the aging of young mountain lions. We thank Walt Meyer (Law Enforcement Division, Nebraska Game and Parks Commission, Chadron, NE) for retrieving the kitten hit by a vehicle and Steve Masek (Wildlife Division, Nebraska Game and Parks Commission, Crawford, NE) and Michael Forsberg for providing information and photographs of mountain lions in Nebraska. We appreciate the time of Thomas Labedz (Collection Manager, Division of Zoology, University of Nebraska State Museum, Lincoln, NE) in preparing the skull and skeleton of the mountain lion kitten.

\section{Literature Cited}

Anderson, C.R., JR., And F.G. Lindzey. 2000. A photographic guide to estimating mountain lion age classes. Wyoming Cooperative Fish and Wildlife Research Unit, Laramie, WY. 2 pp.

Anderson, C.R., JR., F.G. Lindzey, and D.B. McDonald. 2004. Genetic structure of cougar populations across the Wyoming Basin: metapopulation or megapopulation. Journal of Mammalogy 85:1207-1214.

Benedict, R.A., H.H. Genoways, and P.W. Freeman. 2000. Shifting distributional patterns of mammals in Nebraska. Transactions of the Nebraska Academy of Sciences 26:55-84.

Eaton, R.L. And K.A. VerLander. 1977. Reproduction in the puma: biology, behavior and ontogeny. The World's Cats 3:45-70.

Forsberg, M. 2009. Return of the big cat. NEBRASKAland 87:38-43.

Genoways, H.H., And P.W. Freeman. 1996. A recent record of mountain lion in Nebraska. Prairie Naturalist 28:143-145.

Genoways, H.H., J.D. Hoffman, P.W. Freeman, K. Geluso, R.A. Benedict, and J.J. Huebschman. 2008. Mammals of Nebraska: checklist, key, and bibliography. Bulletin of the University of Nebraska State Museum 23:1-92.

Grigione, M.M., P. Beier, R.A. Hopkins, D. Neal, W.D. Padley, C.M. Schonewald, and M.L. Johnson. 2002. Ecological and allometric determinants of home-range size for mountain lions (Puma concolor). Animal Conservation 5:317-324.

Hemmer, H. 1977. Gestation period and postnatal development of felids. The World's Cats 3:90-100.

Hoffman, J.D., AND H.H. GenOWAYs. 2006. Recent records of formerly extirpated carnivores in Nebraska. Prairie Naturalist 37:225-245.

Jones, J.K., JR. 1964. Distribution and taxonomy of mammals of Nebraska. Publications of the Museum of Natural History, University of Kansas 16:1-356.

LAUndRÉ, J.W., AND L. HeRnánDEZ. 2002. Growth curve models and age estimation of young cougars in the northern Great Basin. Journal of Wildlife Management 66:849-858.

Nebraska Game and Parks Commission. 2009. Nebraska wildlife species: white-tailed deer. Lincoln, NE; [cited 15 October 2009]. Available from: http://www .ngpc .state.ne.us/wildlife/wtdeer.asp

Robinette, W.L., J.S. GashWiLER, and O.W. Morris. 1961. Notes on cougar productivity and life history. Journal of Mammalogy 42:204-217.

SETON, E.T. 1929. Cats, wolves, and foxes. Volume 1, part 1, Lives of game animals. Doubleday, Doran \& Company, Inc., Garden City, NY. xxxix + 337 pp.

YounG, S.P., AND E.A. Goldman. 1946. The puma: mysterious American cat. American Wildlife Institute, Washington, DC. xiv +358 pp.

Received 17 July 2009 Accepted 7 December 2009 